\title{
Bódi Ferenc, Fábián Gergely, Thomas R. Lawson (eds.): Local organization of social services in Hungary Crisis - reactions - changes
}

\section{(Studies in comparative social pedagogies and international social work and social policy, 22., EHV, Bremen, 2012. 488 o.) ${ }^{1}$}

\author{
FARKAS JENŐ
}

\begin{abstract}
FARKAS Jenő: tudományos munkatárs, MTA Közgazdaság- és Regionális Tudományi Kutatóközpont Regionális Kutatások Intézete, Kecskemét; farkasj@rkk.hu
\end{abstract}

Jenö FARKAS: research fellow, Institute for Regional Studies, Centre for Economic and Regional Studies, Hungarian Academy of Sciences, Kecskemét; farkasj@rkk.hu

\begin{abstract}
A bemutatott könyv a Local Organization of Social Services (LOSS) elnevezésü nemzetközi tudományos együttmúködés keretében született, amely a helyi szociális ellátórendszerek elméleti és gyakorlati elemzésével foglalkozik. A LOSS mint nemzetközi kooperáció 1993-ban indult el bajor, olasz, finn, angol, amerikai és magyar egyetemek részvételével. Célja, hogy megvizsgálja a helyi szociális ellátórendszerek szerepét a lokális társadalmi erőforrások újratermelésében, illetve hogy egyfajta „hidat” képezzen az amerikai, nyugat-európai és a volt szocialista országok szakemberei között. A kutatóközösség érdeklődése meglehetősen széles, a helyi fejlesztésektől az oktatáson át az egészségügyi ellátás rendszeréig terjed. A recenzió tárgyát képező könyv elsősorban Magyarországra fókuszál, és mint azt az alcíme is mutatja, alapvetően a válságok, az arra adott válaszok és a hosszú távon bekövetkezett változások tanulságait kívánja feltárni a helyi szociális ellátórendszerek vonatkozásában (hasonlóan a klímaváltozást vizsgáló magyar Vahava projekthez). ${ }^{2}$ A témát a 2008-as pénzügyi, majd az abból kibontakozó és hazánkat is erősen érintő gazdasági válság, valamint az annak megoldására irányuló eddigi sikeres és kevésbé sikeres nemzetállami és nemzetek feletti kísérletek inspirálták és teszik aktuálissá. Ez az időszak a helyi szociális ellátórendszerekre mind európai, mind magyar viszonylatban erős nyomást gyakorol(t), sőt sok esetben - a változó körülmények között - megmutatta azok (re)akcióképtelenségét is. A könyv azonban nemcsak az utóbbi pár év történé-
\end{abstract}

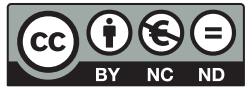


seit elemzi, hanem inkább egyfajta történelmi-kulturális kontextusba helyezi az évtizedek, esetleg évszázadok óta nyomasztó teherként a magyar társadalomra nehezedő problémákat, mint például a népességfogyás, a migráció, a területi egyenlőtlenségek növekedése, a vidéki térségek leszakadása.

A könyvben három tematikai egységben (ezek címei: Helyi szociális ellátórendszerek, Egyenlőtlenségek, valamint Regionális politika - az egyenlőtlenségek kezelése) 18 publikációt találunk 14 szerző tollából. A cikkek mellett külön fel kell hívnom a figyelmet a mellékletre, amely több mint 20 színes térképet és hozzájuk tartozó adattáblákat tartalmaz.

A könyv bemutatása során nem kívánom az összes írást egyenként végigvenni, hanem kutatói érdeklődésem mentén szelektálok azokból, így e helyt kell elnézést kérnem azoktól a szerzőktől, akiknek a munkáit nem említem. Válogatásomba elsősorban a társadalomföldrajz és a regionális tudomány képviselői számára fontos és az ő érdeklődésükre számot tartó publikációk kerültek be.

A könyv programját és elméleti kereteit Soelter és Lawson tanulmánya határozza meg, amelynek címe A jóléti állam fejlődésének szociokulturális modellje. A szerzők e tanulmányukban azt fejtik ki, hogy az egyes nemzetállamok jóléti rendszereinek összehasonlítása nem alapulhat csak a makrotényezők vizsgálatán, hanem az elemzésekben meg kell jelennie a történelmi múltnak és a kulturális hagyományoknak, valamint a globalizáció folyamatának is. Ez az elképzelés szorosan kapcsolódik az elmúlt évtized társadalom-földrajzi (kulturális fordulat) és regionális tudományi kutatási irányaihoz, azoknak egy-egy új szegmensét világítva meg. A jóléti államot érintő kutatásokban ezek segítségével közelebb juthatunk a mikroszerkezet megértéséhez, így sokkal megalapozottabb és pontosabb komparatív vizsgálatokat végezhetünk a tudományterületen elterjedt mintáknál. A cikk rávilágít arra, hogy az ilyen jellegü elemzéseknek nem egyszerüen az adott országban működő jóléti rendszerek leírását kell adniuk, hanem a történelmi múltból, a kulturális gyökerekből, a hagyományokból és a globalizáció hatásaiból kell levezetniük azt, hogy ki a felelős a jólét biztosításáért, hogy az egyén szintjén milyen ideológiai mintákat alkalmaznak az egyes szolgáltatások nyújtásakor, illetve hogy e tényezők összegződéseként egy-egy nemzetállamban milyen jóléti kultúra alakult ki. Ebben a megközelítésben tehát nem jóléti rendszereket, hanem jóléti kultúrákat hasonlítunk össze, amely jóval tágabb fogalmi kört jelent, mint egy adott államban az állampolgárok számára elérhető szociális szolgáltatások köre.

A Helyi szociális ellátórendszerek címü fejezetben Soelter és Lawson cikke után olyan publikációkat találunk, amelyek a kötet alapkoncepciójának megfelelően történelmi perspektívába helyezve mutatják be a magyar jóléti rendszer fejlődését, mint például Bódi Ferenc A szociális ellátórendszer kifejlődése Magyarországon, történeti háttér, nemzeti sajátosságok című írása. A cikk a két világháború közötti időszaktól (néha a dualizmus koráig tartó mélyfúrásokkal) 2010-ig tekinti át röviden az azóta eltelt három korszak (két világháború között, szocializmus, a rendszerváltás után) alapvető jellemzőit. A cikk fontos erénye, hogy nemcsak szociális ágazati, hanem területi szempontok is érvényesülnek benne. 
Ennek megfelelően több esetben kitér a különböző térségi problémákra, mint például a vidék hátrányos helyzetére, a vidékfejlesztésre, az ország modernizációjának területi folyamataira és azok különbségeire is.

A következő kiválasztott munka Bódi Ferenc és Bódi Mátyás írása, amely a Népességfogyás, elöregedés, kisiklott fejlődési pályák címet viseli. A szerzők a cikk első felében történelmi távlatokban elemzik hazánk demográfiai helyzetének alakulását, azonban nemcsak a közvetlen népesedési problémákra, hanem a tágabb összefüggésekre és az ok-okozati viszonyokra is felhívják a figyelmet. E gondolatsor végén pedig rávilágítanak arra, hogy a jelen helyzet megoldásához teljes társadalmi-gazdasági paradigmaváltásra van szükség hazánkban. Az írás második része egyrészt az elkövetett hibák részletesebb elemzését adja, másrészt előkészíti, megindokolja a szerzők által sajnos csak vázlatosan felvillantott megoldási irányokat. A cikk legfontosabb megállapítása, hogy a magántőke nem szereti a leszakadó régiókat (a szerzők elsősorban Északkelet-Magyarországot említik), továbbá hogy a rendszerváltás utáni fejlesztések sok esetben nem hoztak valódi innovációkat, így új lökést sem tudtak adni a térségi gazdaságok szerkezetváltásához. A lényegében összeszerelő jellegü, sok esetben low-tech beruházások nem eredményeztek érdemi javulást a foglalkoztatásban sem, sőt egyfajta kettős (szigetszerüen működő) gazdaság kialakulását segítették elő. Ez utóbbi a szerzők értelmezésében azt jelenti, hogy az üzemek nem épültek be szervesen a lokális gazdaságokba, hatásuk inkább csak makroszinten, az export erősödésében jelentkezik. A központi kormányzat eközben ugyan az elmaradott területekre allokálta a forrásokat, de nem egy meghatározott stratégia alapján, hanem a politikai lobbijátszmáknak alárendelve tűzte ki a fejlesztési célokat, ún. kijáró fejlesztési modellt meghonosítva. Mindez a helyi gazdaságok szétesése mellett konzerválta a magas munkanélküliséget. Az e folyamatok mellett működő torz szociális rendszer pedig a leszakadó régiók képzetlen tömegeit a munkanélküli lét fenntartására ösztönözte, ami végül a helyi társadalmak lecsúszásához vezetett. A társadalmi felemelkedésnek és így a demográfiai problémák megoldásának feltételeit és irányait az alkotók hét pontban foglalják össze, melyek lényege, hogy az oktatástól a szociális rendszeren át a jóléti kultúránk alapjait kell megváltoztatni, újraépíteni. A változás fó eleme a komparatív előnyökre alapozó új fejlődési utakat nyitó gazdaságfejlesztés lehet, amely megélhetést biztosítana a leszakadó régiókban élő családok számára.

A fejezetből utolsóként Fónai Mihály A települési közösségek problémáinak és igényeinek hatása a helyi politikára című cikkét emelném ki. A tanulmányban a szerző korábbi empirikus kutatásaira alapozva tárja fel, hogy a helyi közösségek vélt vagy valós problémái és igényei milyen módon és mértékben befolyásolják a lokális politikát és a helyben nyújtott közszolgáltatásokat. A kérdéskör elemzésekor külön figyelmet szentel a romák helyzetének és véleményének, amelyek az eredmények szerint néhány területen jelentősen különböznek a többségi társadalométól. A romák például nagyobb problémának érzékelik szegénységüket, megoldatlan lakáshelyzetüket, ugyanakkor kevésbé foglalkoznak 
a betegségekkel és a pszichés panaszokkal, mint a nem romák. Ennek hátterében a szerző szerint a roma lakosság eltérő életkori struktúrája, valamint tényleges jövedelmi és lakáshelyzete állhat. A felmérések eredményei alapján a lakosság személyes gondjai elsősorban a szociális, foglalkoztatási és egészségügyi ellátási területeken gyakorolnak nyomást az önkormányzatokra. Abban a vonatkozásban, hogy honnan kapnak segítséget a problémák megoldására, szintén vannak különbségek a romák és a nem romák között. A roma válaszadók sokkal kevésbé számíthatnak a családjukra, illetve nagyobb arányban érzik úgy, hogy a gondjaikkal soha senki nem foglalkozott. Meglepő viszont az, hogy a lehetséges támogatók között a megkérdezettek - és ebben nincs különbség romák és nem romák között - egyszer sem említették az önkormányzati képviselőket, a polgármesteri hivatal munkatársait, az egyházakat vagy a civil szervezeteket. Ezzel mutat párhuzamot, hogy a lakosság elsősorban az informális támogató rendszerekre kíván támaszkodni (nem bízik a formális rendszerben és így nem is számít rá). Ugyanakkor a romák esetében a baráti és munkakapcsolatok hiánya miatt a formális rendszerek közül a polgármesteri hivatal is megjelenik a lehetséges segítségnyújtók között. A szerző a cikk utolsó harmadában a szociális és támogatórendszerhez kapcsolódó, a helyi fejlesztések irányaira vonatkozó lakossági elvárásokat elemzi. Ennek legfőbb tanulsága talán az, hogy a munkanélküliség, a munkalehetőség hiánya általános problémaként jelenik meg, és ennek helyben történő megoldását a megkérdezettek közjóként, szinte közszolgáltatásként értelmezik. Az eredmények között azonban itt is van különbség a romák és a nem roma többség között, amit ez esetben is alapvetően a két csoport helyzetének különbségeivel magyaráz a szerző. A nem romák az infrastrukturális ellátottságot vagy a sportolási lehetőségeket tartják fontosnak, míg a romák például a bérlakások hiányát gondolják súlyos problémának. A cikk eredményeinek és a szerző következtetéseinek részletesebb bemutatása terjedelmi korlátok miatt itt nem lehetséges, ugyanakkor megismerésük mind a regionális tudomány, mind a település- és a társadalomföldrajz művelői számára érdekesek lehetnek, hiszen további elméleti és gyakorlati következtetésekre, továbbgondolásra inspirálnak.

A második, Egyenlőtlenségek című fejezetből elsőként Obádovics Csilla, Bruder Emese és Kulcsár László közös publikációját választottam, amely A gazdasági és szociális helyzet területi egyenlötlenségei a vidéki Magyarországon - hasonlóságok és eltérések címet viseli. A szerzők célja a területi differenciálódás új eszközökkel való bemutatása volt, melyhez humán szegénységi indexet, valamint jövedelmi rést (a jövedelmek felső és alsó decilise közti távolság) számítottak, és ezt vetették össze más mutatókkal, mint például a munkanélküliséggel vagy a térségek vidéki jellegével. A módszertanilag érdekes és újszerű kutatási munka eredményeként megállapították, hogy a szegénységi index alkalmazásával is kimutatható a magyar kistérségek erős polarizáltsága. Emellett ezt a mutatót a jövedelmi réssel összevetve kimutatták, hogy a szegényebb kistérségeken belül a települések között jellemzően kis jövedelmi különbségek vannak, míg a „gazdagabbak" nagy részében ezek a jövedelmi különbségek nagyon nagyok. Végkövet- 
keztetésük szerint a társadalmi-gazdasági egyenlőtlenségek viszonylatában már ismert tradicionális kelet-nyugati lejtő még napjainkban is releváns, ugyanakkor a társadalmi, gazdasági, jövedelmi és szociális jelenségek között nem egyszerủ okokozati kapcsolat van, hiszen ezek egyszerre tekinthetők oknak és következménynek is. Ebből következően a szerzők úgy látják, hogy a polarizáltság csak hosszú távon szüntethető meg.

A második fejezetből kiemelhető továbbá Fábián Gergely és Takács Péter A válság és az egyenlötlenségek alakulása - egy lokális példa című munkája. Az esettanulmányban Nyíregyháza példáján dolgozzák fel a 2008-as pénzügyi válság lokális hatásait lakossági kérdőíves felméréssel. Eredményeik szerint azok, akik a válság hatására vesztették el munkájukat, két év múltán, 2010-ben is állás nélkül voltak. Különösen a férfiakat érintette ez a jelenség, amelynek hatására foglalkoztatottságuk 3\%-kal csökkent a városban, bár a nőkre vonatkozó adatok is kedvezőtlenek. A kormányzati és helyi megszorító intézkedések a válság hatását tovább fokozták a közalkalmazotti szféra leépítésével. A szerzők eredményei szerint a jövedelmi helyzet is romlott a bérek „befagyasztása” miatt, ami kb. 7\%-os reálbércsökkenést jelentett a 2008-2010 közötti időszakban. Ezzel párhuzamosan a szegénységi ráta növekedését és a jövedelmi egyenlőtlenségek erősödését is megfigyelték. Ez utóbbi folyamatok elsősorban a középréteg kárára következtek be, bár szintén kimutatták, hogy kis számban ugyan, de nyerteseket is találhatunk a helyi társadalomban. E folyamatokkal összefüggésben megállapították, hogy alapvetően a pénzbeli juttatások felé tolódott el a szociális támogatások és ellátások felé irányuló igény szerkezete. Eredményeik alapján azt mondhatjuk, hogy a 2008-ban elindult globális válság az első jóslatok ellenére kifejezetten mélyen érintette a magyar társadalmat (és nem csak a devizahitelek vonatkozásában).

A harmadik és egyben utolsó fejezetben mindössze egyetlen cikket találunk Bódi Ferenc és Fekete Attila tollából, Magad uram, ha szolgád nincsen címmel. A publikáció a vidéki társadalom politikai aktivitásával foglalkozik. A szerzők településkategóriák és státuszcsoportok mentén vizsgálták a választási aktivitást, valamint a helyi fejlesztésekben és a közéletben való részvételt. A módszertanilag is érdekes cikkben megállapítják, hogy a vidéki társadalom nincs apátiában, a helyi ügyek alakulását figyelemmel kísérik, ugyanakkor az országos politikától egyfajta távolságtartás érzékelhető a lakosság körében. Vizsgálataikban emellett azt is igyekeztek feltárni, hogy az emberek a települési fejlettség és a társadalmi státusz mentén hogyan ítélik meg a helyi politika működését, fejlesztésben elért teljesítményét. A települési fejlettséget illetően a legszembetűnőbb eredmény, hogy a leghátrányosabb helyzetű településeken lakók kifejezetten várják az állam segítségét, míg a stabilan hátrányos helyzetűek ${ }^{3}$ polgárai inkább csak szükebb környezetükre számítanak. A státuszcsoportok között a véleménybeli eltérések még kisebbek, mint a településkategóriák mentén. Véleménykülönbségeket különösen a helyi elit és a civil kezdeményezések szerepében, problémamegoldó képességében sikerült kimutatni. A nyugdíjasok például sokkal jobban bíznak a lokális poli- 
tikai vezetésben, mint a civilekben. Publikációjuk végén azt az érdekes felvetést fogalmazzák meg a szerzők, hogy ha az eredményeket e két szemponttól eltekintve vizsgáljuk meg, akkor a vidéki társadalmat alapvetően két táborra lehet bontani: a „centristákra”, akik a központi hatalomtól várják a megoldást, és a „municipialistákra”, akik inkább a helyi erőforrásokban és tudásban bíznak. Ennek a felismerésnek a bizonyításához további kutatásra lenne szükség, ugyanakkor az eredmény segítene megválaszolni azt a régóta nyitott kérdést, hogy egyáltalán milyen helyi fejlesztéspolitika lehet elfogadott és sikeres Magyarországon.

Szót kell ejteni a Mellékletek színes térképeiről is, amelyek a kutatás során keletkeztek. Az anyag néhány hosszabb trendet bemutató térkép mellett a 2009es, 2010-es társadalmi, gazdasági folyamatokat mutatja be. Ezek a térképek mind a társadalom- és gazdaságföldrajzosok, mind a regionalisták számára módszertanilag is érdekesek lehetnek. Példaként a járadékosok arányának egyszerü, de hatásos összegzését említhetjük (2011-től sajnos ezt a jogszabályi változások miatt módszertanilag így elkészíteni már nem lehet) vagy éppen a választásokon való lakossági aktivitás ábrázolását, amelyek jól szemléltetik, hogy más tudományágak területi elemzési módszereit, alkalmazott mutatóit is érdemes figyelemmel követni munkánk során.

Végezetül a recenziót azzal zárnám, hogy kiknek is ajánlom e könyvet. A 18 tanulmány mindegyikét a terjedelmi korlátok miatt nem mutathattam be, azonban elmondható, hogy a recenzióból kimaradtak hasonlóan magas színvonalúak, mint az ismertetettek. A szerzők a témakifejtés során mindig törekedtek az ágazati szempontok mellett a területi, térségi összefüggéseket is feltárni és ezeket történelmi perspektívába helyezni, így a publikációk jelentős része egy-egy téma hazai vonatkozásainak összefoglalását adja. Következésképp nemcsak a társadalom- és gazdaságföldrajzzal vagy a regionalizmussal foglalkozó kutatók, hanem az e témákkal most ismerkedők, diákok számára is jó szívvel ajánlható a kötet.

\section{Jegyzetek}

1 A könyvnek egy magyar nyelvü, némileg eltérő tartalmú változata is az olvasók rendelkezésére áll: Bódi F., Fábián G., Lawson, T. A. (2011): Helyi szociális ellátórendszer Magyarországon. Debreceni Egyetemi Kiadó, Debrecen. A kötet a következő webcímen érhető el: http://www.mtapti.hu/loss/?p=articles\&article_id=3\&lang_id=1\&list_limitFrom

2 A Vahava (Változás-hatás-válaszadás) projekt 2003-ban indult Láng István akadémikus vezetésével. Célja a klímaváltozás irányainak és hatásainak feltárása, a lehetséges válaszok kidolgozása volt. A kutatás eredményei nagyban hozzájárultak a Nemzeti éghajlat-változási stratégia megalapozásához.

3 A szerzők a területfejlesztés szempontjából hátrányos helyzetű térségekre vonatkozó 1992-es, 2004-es és 2007-es jogszabályok minősítése alapján sorolták be a településeket fejlettségi típusokba. A vizsgálatban azok a települések kerültek a stabilan hátrányos helyzetű csoportba, amelyek mindhárom évben hátrányos helyzetủek voltak e rendelkezések szerint. 


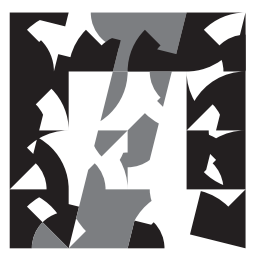

TÉR ÉS TÁRSADALOM | SPACE AND SOCIETY 